\title{
A More Informative Way to Name Plutonic Rocks- Comment by Hogan
}

\author{
John P. Hogan, Dept. of Geological Sciences and Geological Engineering and Petroleum Engineering, Missouri University of \\ Science and Technology, Rolla, Missouri 65409, USA
}

Glazner et al. (GSA Today, Feb. 2019) propose major modifications to the International Union of Geological Sciences (IUGS) classification of igneous rocks (see Streckeisen, 1976; Le Maitre, 2002) to correct what they see as major shortcomings, including: (1) consanguineous, mappable, igneous rock bodies can exhibit modal variation requiring multiple rock names to describe; (2) these names rarely convey information regarding rockforming processes or tectonic settings; and (3) their discussion imparts the perception that their "quantitative" approach corrects these problems. In addition, they portend the "qualitative" nature of the IUGS system inhibits the use of artificial intelligence (AI) for data mining and analysis of igneous rocks. I present several points for consideration and recommend against adopting Glazner et al.'s (2019) suggestions.

The strength(s) of the IUGS system are as follows: (A) It is a quantitative classification scheme based upon modal abundances of minerals in the rock sample, which can be measured, with associated uncertainties, following well-known procedures (see Chayes, 1956). Quantitative modal analysis is accomplished at many scales: thin-sections (Willis et al., 2017), hand-samples (Elliott, 1999), and mapscale or pluton/batholith-scale using multiple hand samples (see Figure 7 in Hogan and Sinha, 1989). (B) Procedures for classifying rocks using this data are self-consistent and easily followed. A root name (e.g., granodiorite) is assigned using normalized modal abundances of major minerals (e.g., quartz, alkali feldspar, plagioclase). (C) The IUGS classification scheme does include the abundance and identity of minor and accessory minerals in naming the rock. Modifiers reflect the modal abundance of mafic minerals ("color index" "M") of the rock (e.g., leucocratic granodiorite). Trends in $\mathrm{M}$ are readily discernible using the IUGS scheme (Figure 13 in Streckeisen, 1976; Figure 8 in Wones, 1980). (D) The identity of minor and accessory minerals is included in the name according to their modal abundance, with greater abundance closer to the root name (e.g., leucocratic, titanite, hornblende, biotite, granodiorite). (E) Preliminary rock names, based upon "rough" estimation (i.e., using charts as a visual aid) of modal abundance (e.g., a leucocratic, biotite, hornblende granitoid) are used until the alkali feldspar/plagioclase ratio is constrained (Figure 6 in Streckeisen, 1976). (F) The IUGS procedure is quantitative, readily reproducible, easily followed, and understood by geoscientists worldwide.

The IUGS classification scheme is compatible with mapping heterogeneous igneous rocks. Sedimentary strata commonly consist of multiple rock types, interbedded at several scales, with sharp or gradational contacts, and are mapped as a "formation" without abandoning well-established sedimentary nomenclature. Heterogeneous intrusive igneous rocks, composed of multiple rock types with gradational contacts, can be mapped as lithodemes or as suites (e.g., Tuolumne Intrusive Suite; see Easton et al., 2016) without abandoning well-established IUGS nomenclature for igneous rocks. The description of the physical characteristics of the rock types, nature of the contacts, comprising mappable lithodemes or suites, along with the IUGS names, are included in its formal description.

The motivation for classification schemes is an important and fundamental subject for all students investigating a topic of interest. Classification schemes can be largely objective, based upon measurable and reproducible facts, and internally consistent rules. Alternatively, classification schemes can be interpretive and based upon inferred parameters. Each type of classification scheme serves an important scientific purpose. Glazner et al. (2019) suggest transforming the objective IUGS classification scheme into an interpretive classification scheme where wellestablished taxonomy are repurposed to convey a vision of how igneous rocks form. The example they use is "granodiorite" and propose this term to become synonymous with a subduction zone setting. Unfortunately, such classification schemes tend to be transient, as leucocratic biotitemuscovite granite is not universally accepted as an S-type granite, nor are gradational lit-par-lit contacts considered proof of granitization. In contrast, by keeping observations (modal data) separate from interpretation (e.g., zone refining) the integrity of names determined by correct application of the IUGS classification scheme (e.g., hornblende-biotite granodiorite) will continue to hold factual meaning worldwide, well into the future, despite any interpretation of the tectonic setting or the processes by which a rock formed (see Streckeisen, 1976, p. 4, section "Principles of Classification").

Scientific classification schemes are challenged by imposing order on the continuum that is the natural world. This is evident in every science discipline including biology despite the oversimplification of "doggish cats" and "cattish dogs" manufactured by Glazner et al. (2019). For example, lichens are living organisms that are neither a fungi nor a cyanobacterium but a blend (DePriest, 2004). Their form bears no resemblance to either organism(s) from either Kingdom that make up the lichen. Many life forms are continuums and present 
taxonomical challenges, which will be understood, not by text-mining alone, but by publishing accurate, precise, and reproducible biological findings (Gough, 2017). The contributors to the IUGS classification scheme, recognizing that many rock suites are continuums, devoted considerable thought in choosing the boundaries, knowing that this property of rocks does not invalidate the general usefulness of the proposed classification scheme (see Streckeisen, 1976). The petrological community needs to increase the opportunity to explore petrological trends in the variation of mineral assemblages that define igneous rock suites using AI and continue to debate possible origins for these trends. To do so, I recommend petrologists continuing to use the IUGS classification scheme and focusing their energy on seeking publication of accurate and reproducible modal analysis data in consistent formats (i.e., similar to geochemical data) suitable for data mining.

\section{REFERENCES CITED}

Chayes, F., 1956, Petrographic Modal AnalysisAn Elementary Statistical Appraisal: New York, John Wiley and Sons Inc., $139 \mathrm{p}$.

DePriest, P.T., 2004, Early molecular investigations of lichen-forming symbionts: 1986-2001: Annual Review of Microbiology, v. 58, p. 273-301, https://doi.org/10.1146/annurev .micro.58.030603.123730.

Easton, R.M., Edwards, L.A., Orndorff, R.C., and Ferrusquia-Villafranca, I., 2016, North American Commission on Stratigraphic Nomenclature Report 12: Stratigraphy, v. 13, no. 3, p. 220-222.

Elliott, B.A., 1999, Colour masks in digital image analysis: A technique for modal analyses of quartz saturated plutonic rocks: Bulletin of the Geological Society of Finland, v. 71, no. 2, p. $233-241$, https://doi.org/10.17741/bgsf/ 71.2.002.

Glazner, A.F., Bartley, J.M., and Coleman, D.S., 2019, A more informative way to name plutonic rocks: GSA Today, v. 29, p. 4-10, https://doi.org/10.1130/GSATG384A.1.

Gough, N.R., 2017, Challenges in Classifying Biology: BioSerendipity, https://www.bio serendipity.com/challenges-in-classifyingbiology/ (accessed 21 Mar. 2019).

Hogan, J.P., and Sinha, A.K., 1989, Compositional variation of plutonism in the Coastal Maine Magmatic Province: Mode of origin and tectonic setting, in Tucker, R.D., and Marvinney, R.G., eds., Studies in Maine Geology-Igneous and Metamorphic Geology: Maine Geological Survey Department of Conservation, v. 4, p. 1-33.

Le Maitre, R.W., Streckeisen, A., Zanettin, B., LeBas, M.J., Bonin, B., and Bateman, P., editors, 2002, Igneous Rocks: A Classification and Glossary of Terms: Cambridge, Cambridge University Press, https://doi.org/10.1017/ CBO9780511535581.

Streckeisen, A., 1976, To each plutonic rock its proper name: Earth-Science Reviews, v. 12, p. 1-33, https://doi.org/10.1016/0012-8252 (76)90052-0.

Willis, K.V., Srogi, L., Lutz, T., Monson, F.C., and Pollock, M., 2017, Phase Composition Maps integrate mineral compositions with rock textures from micrometer to the thin section scale: Computers \& Geosciences, v. 109 , p. 162-177, https://doi.org/10.1016/ j.cageo.2017.08.009.

Wones, D.R., 1980, Contributions of crystallography, mineralogy, and petrology to the geology of the Lucerne Pluton, Hancock County, Maine: The American Mineralogist, v. 65 , p. $411-437$.

ManusCript ReCeived 4 Mar. 2019

ManUSCRIPT ACCEPTED 11 Mar. 2019 